J URNAL HUKUMREPLK

Volume 5 No. 2, September 2017

P-ISSN: 2337-9251, E-ISSN: 2597-9094

Open Access at : http://jurnal.umt.ac.id/index.php/replik/index

\title{
PRAKTIK PENERAPAN PERATURAN MENTERI KESEHATAN NOMOR 290 TAHUN 2008 TENTANG PERSETUJUAN TINDAKAN KEDOKTERAN (INFORMED CONSENT) PADA PELAYANAN GAWAT DARURAT DI RUMAH SAKIT
}

\author{
Yulia Kusuma Wardani \& M. Fakih \\ Fakultas Hukum Universitas Lampung \\ Email:yulia_as@yahoo.com
}

\begin{abstract}
Abstrak
Secara normal pelayanan medis di rumah sakit selalu diawali dengan sebuah persetujuan yang dituangkan dalam bentuk informed consent. Informed consent itu sendiri pada prinsipnya adalah persetujuan dari pasien dan keluarganya atas tindakan medis yang akan dilakukan setelah mendapatkan penjelasan dari dokter. Namun demikian dalam keadaan darurat informed consent secara hukum dapat ditiadakan. Permasalahan dalam penelitian ini adalah, pertama: Bagaimana penerapan informed consent dalam praktek pelayanan kesehatan pada pasien gawat darurat di rumah sakit? Kedua, Apa yang menjadi hambatan dalam pelayanan gawat darurat di rumah sakit beserta aspek hukumnya? Ketiga, Bagaimana seyogyanya penerapan informed consent dalam pelayanan gawat darurat di rumah sakit? Penelitian ini dilakukan dengan menggunakan data sekunder maupun data primer. Data sekunder diperoleh melalui studi pustaka dan dokumen, sedangkan data primer diperoleh melalui informasi dari para informan baik tenaga medis (dokter) dan perawat yang pernah bertugas di Instalasi Gawat Darurat (IGD). Hasil penelitian dan pembahasan menunjukkan, bahwa penerapan informed consent pada pasien gawat darurat di rumah sakit, pada prinsipnya telah mengikuti peraturan yang berlaku. Namun demikian, masih timbul kekhawatiran di kalangan tenaga kesehatan bahwa tidak adanya informed consent akan menimbulkan tuntutan dari keluarga pasien. Hambatan pelayanan gawat darurat di IGD adalah pada umumnya keluarga pasien tidak memahami prosedur pelayanan medis di IGD yang mengenal sistem triase, adanya perluasan operasi (extended operation) yang mungkin timbul dan adanya teamwork yang kurang efektif. Penerapan informed consent dalam pelayanan gawat darurat di IGD secara yuridis mengandung makna adanya penyimpanganpenyimpangan terhadap kaedah medis. Namun penyimpangan yang dimaksud merupakan pengecualian, bahwa penyimpangan tersebut tidak dikenakan sanksi dan dibenarkan secara hukum
\end{abstract}

Kata kunci: informed consent, gawat darurat, tindakan medis 


\section{PENDAHULUAN}

Rumah sakit adalah fasilitas pelayanan kesehatan yang menyelenggarakan pelayanan kesehatan perorangan secara paripurna yang menyediakan pelayanan rawat inap, rawat jalan, dan gawat darurat. Rumah sakit dalam memberikan pelayanan kesehatan kepada pasien harus memberikan sejumlah informasi yang memadai. Informasi tersebut meliputi diagnosis dan tata cara tindakan medis, tujuan tindakan medis, alternatif tindakan, risiko dan komplikasi yang mungkin terjadi, dan prognosis terhadap tindakan yang dilakukan serta perkiraan biaya pengobatan. Melalui informasi tersebut, pada dasarnya pasien berhak memberi persetujuan tindakan medis (informed consent) atau menolak (informed refusal) atas tindakan yang akan dilakukan oleh tenaga kesehatan khususnya dokter terhadap penyakit yang dideritanya. Dengan kata lain, dalam kondisi normal bukan dalam keadaan gawat darurat setiap tindakan medis yang akan dilakukan di rumah sakit harus mendapat persetujuan pasien atau keluarganya.

Selanjutnya, rumah sakit sebagai institusi pelayanan kesehatan juga memberikan pelayanan gawat darurat. Secara yuridis keadaan gawat darurat memiliki karakteristik khusus dan spesifik $^{1}$ serta cenderung menimbulkan (therapeutic privilege $)^{2}$ tertentu bagi tenaga kesehatan dan rumah sakit. Prinsip dalam keadaan darurat adalah harus segera dan secara langsung diambil tindakan penyelamatan pasien. $^{3}$ Dalam kasus gawat darurat, pada prinsipnya hukum telah memberikan pengecualian terhadap kewajiban informed consent. Secara luas ada beberapa pihak yang dikecualikan dari kewajiban informed consent yaitu: ${ }^{4}$

${ }^{1}$ Hubungan dokter-pasien dalam keadaan gawat darurat sering merupakan hubungan yang spesifik. Dalam keadaanbiasa (bukan keadan gawat darurat) maka hubungan dokter dan pasien didasarkan atas kesepakatan kedua belah pihak, yaitu pasien dengan bebas dapat menentukan dokter yang akan dimintai bantuannya (didapati azas voluntarisme). Demikian pula dalam pelayanan selanjutnya, kewajiban yang timbul pada dokter berdasarkan pada hubungan yang telah terjadi sebelumnya (pre-existing relationship). Dalam keadaan darurat hal tersebut dapat tidak ada dan azas voluntarisme dari keduabelah pihak juga tidak terpenuhi. Untuk itu perlu diperhatikan azas yang khusus berlaku dalam pelayanan gawat darurat yang tidak didasari atas azas voluntarisme.

${ }_{2}$ Menurut Kartono Muhammad, therapeutic privilege merupakakan hak keistimewaan yang diberikan kepada dokter untuk menetapkan jenis tindakan medic tanpa memberi informasi, jika ada keyakinan bahwa pemberian informasi justru dapat memperburuk keadaan emosiaonal pasien, yang kemudian dapat mempersulit perawatan atau pengobatan selanjutnya.

${ }^{3}$ Konsep penanganan pasien gawat darurat adalah penyelamatan pasien (time saving is life and limb saving), karena sangat terbatasnya waktu tanggap (respon time) untuk menyelamatkan jiwa dan atau anggota gerak pasien, maka penanganan harus sistematik dan berskala prioritas. Tindakan yang dilakukan harus cepat, tepat dan cermat sesuai dengan standar.

${ }^{4}$ Munir Fuady,2005. Sumpah Hippocrates (Aspek Hukum Malpraktik Dokter), Penerbit Citra Aditya Bhakti, Bandung. Hlm. 65-66 
1. Pihak yang belum bisa mengambil putusan secara mandiri. Misalnya terhadap anak di bawah umur.

2. Pihak yang memang tidak dapat memberikan keputusan yang rasional. Misalnya orang sakit ingatan atau keterbelakangan mental, yang dalam hal ini persetujuan harus diberikan oleh pengampu atau walinya.

3. Pihak yang untuk sementara tidak bisa memberi persetujuan, seperti pasien gawat darurat, tidak sadar diri, dan lain sebagainya sementara keluarganya tidak dapat dihubungi.

4. Therapeutic privilege, yaitu jika dokter dapat membuktikan bahwa dokter tersebut mempunyai keyakinan yang layak (reasonable belief) bahwa membuka informasi kepada pasien akan lebih membahayakan diri pasien tersebut, misalnya informasi yang mengakibatkan menimbulkan efek psokologis yang tidak baik terhadap pasien.

Berdasarkan uraian di atas, nampak bahwa dalam keadaan gawat darurat untuk menyelamatkan jiwa pasien tidak diperlukan persetujuan tindakan medis (informed consent). Kondisi demikian secara eksplisit tertuang dalam penjelasan ketentuan Pasal 45 ayat (1) Undang-Undang No. 29 Tahun 2004 tentang Praktik kedokteran yang berbunyi: "Dalam keadaan gawat darurat untuk menyelamatkan jiwa pasien tidak diperlukan persetujuan tindakan medis (informed consent). Dengan demikian, berdasarkan ketentuan hukum positif bahwa dalam keadaan darurat pelayanan kesehatan di rumah sakit informed consent dapat dikesampingkan.

Melalui ketentuan tersebut, jelas bahwa penerapan informed consent dalam keadaan gawat darurat memerlukan pengecualian-pengecualian dan kondisi ini sesuai dengan asas hukum bahwa penyimpangan-penyimpangan atau pengecualianpengecualian akan memperkuat berlakunya asas yang bersifat umum. ${ }^{5}$ Apa yang tertuang dalam ketentuan di atas, pada prinsipnya memberi keleluasaan kepada tenaga kesehatan di rumah sakit untuk tetap memberi pelayanan kesehatan pada pasien dalam keadaan gawat darurat. Berdasarkan hasil pra-riset yang telah dilakukan, khususnya di

\footnotetext{
${ }^{5}$ Mengenai penyimpangan atau pengecualian terhadap asas hukum dalam Buku Teori Hukum yang ditulis oleh Sudikno Mertokusumo, 2011. Pernerbit Universitas Atmajaya Yogyakarta, Hlm. 4647, dikemukakan bahwa: "asas hukum ini sifatnya umum, yang berarti bahwa dapat berlaku dalam berbagai situasi, maka membuka peluang akan adanya penyimpangan-penyimpangan atau pengecualian-pengecualian. Penyimpangan-penyimpangan atau pengecualian-pengecualian itulah yang memperkuat berlakunya asas yang bersifat umum (exeptio probat regulam, de uitzonderingen bevestegen de regel). Dalam konteks ini contohnya adalah penerapan informed consent dalam keadaan gawat darurat.
} 
rumah sakit kelas B milik Pemerintah Daerah di wilayah Bandar Lampung, pasien yang masuk ke Instalasi Gawat Darurat (IGD) selama 24 jam kurang lebih jumlahnya sekitar 200-300 pasien. Demikian juga di rumah sakit kelas C milik swasta di Bandar Lampung, pasien yang masuk IGD berkisar 50-100 pasien selama 24 jam.

Dengan melihat jumlah pasien tersebut tentunya akan membawa konsekuensi dalam pelayanan medis yang akan dilakukan. Fakta yang terjadi sering kali pasien gawat darurat tidak didampingi oleh keluarganya, misalnya pasien kecelakaan lalu lintas. Padahal di sini rumah sakit melalui tenaga kesehatan harus bertindak segera demi menyelamatkan jiwa pasien. Namun demikian pernah terjadi setelah dilakukan tindakan medis yang sesuai dengan standar profesi dan standar prosedur operasional tanpa informed consent, keluarga pasien menuntut dengan alasan tindakan yang telah dilakukan tidak mendapat persetujuan keluarga pasien. Kondisi demikian, pada saat ini merupakan masalah bagi rumah sakit dan tenaga kesehatan khususnya di ruang IGD. Padahal, secara hukum sudah dibenarkan bahwa rumah sakit dapat bertindak tanpa informed consent, namun dalam praktiknya tidak demikian. Dalam konteks inilah, telah terjadi kesejangan antara das sollen dan das sein dalam pelayanan kesehatan khususnya bagi pasien gawat darurat. Oleh karena itu, berdasarkan latar belakang di atas, kiranya perlu dilakukan penelitian tentang praktik penerapan informed consent pada pelayanan gawat darurat di rumah sakit. Berdasarkan latar belakang di atas, yang menjadi permasalahan pokok adalah mengenai penerapan informed consent pada pasien gawat darurat di rumah sakit, maka yang menjadi rumusan dalam penelitian ini adalah:

1. Bagaimana penerapan informed consent dalam praktek pelayanan kesehatan pada pasien gawat darurat di rumah sakit?

2. Apa yang menjadi hambatan dalam pelayanan gawat darurat di rumah sakit beserta aspek hukumnya?

3. Bagaimana seyogyanya penerapan informed consent dalam pelayanan gawat darurat di rumah sakit?

\section{METODE PENELITIAN}

Penelitian tentang "Praktik Penerapan Permenkes No. 290 Tahun 2008 Tentang Persetujuan Tindakan Kedokteran (Informed Consent) Pada Pelayanan Darurat Di Rumah Sakit." merupakan penelitian deskriptif, artinya penelitian ini berusaha untuk 
menjelaskan secara konkrit dan terperinci tentang suatu keadaan nyata serta aspek hukumnya pada pelayanan gawat darurat di rumah sakit. Pendekatan yang digunakan adalah melalui pendekatan normatif dan sosiologis. Pendekatan normatif meliputi penelitian terhadap asas hukum, pengertian hukum dan ketentuan-ketentuan hukum. Sebagai penelitian yang bersifat normatif, penelitian ini menitikberatkan pada penelitian kepustakaan. Selanjutnya, pendekatan sosiologis dilakukan melalui penelitian lapangan. Penelitian ini dilakukan melului dua jenis penelitian yaitu: penelitian kepustakaan dan penelitian lapangan. Jenis data dalam penelitian kepustakaan adalah data sekunder berupa kaedah atau norma yang meliputi asas-asas hukum, pengertian hukum dan ketentuan-ketentuan hukum yang berkaitan dengan aspek hukum pada pelayanan kesehatan gawat darurat. Data sekunder dalam penelitian ini meliputi bahan hukum primer, sekunder dan tertier. Alat yang digunakan untuk mengumpulkan data sekunder adalah studi dokumen yaitu dengan cara mempelajari ketiga macam bahan hukum primer, sekunder dan tersier.Penelitian lapangan dilakukan dengan mengumpulkan data primer yang diperoleh melalui beberapa responden dan informan. Penelitian ini dilakukan di Bandar Lampung dengan pertimbangan bahwa di wilayah tersebut terdapat rumah sakit umum kelas B yang merupakan rumah sakit rujukan terbesar di Provinsi Lampung dengan jumlah pasien gawat daruratnya mencapai 200-300 pasien per-24 jamnya. Selain itu, juga diperbandingkan dengan rumah sakit kelas $\mathrm{C}$ yang jumlah pasien gawat daruratnya mencapai 50-100 pasien per-24 jamnya. Populasi dalam penelitian ini adalah para tenaga kesehatan terutama dokter dan perawat yang bekerja di rumah sakit kleas B maupn Kelas C. Kedua tenaga kesehatan tersebut diambil dengan pertimbangan bahwa mereka adalah tenaga kesehatan yang secara langsung perhubungan dengan pelayanan pasien gawat darurat terutama di IGD. Selanjutnya, untuk menentukan sampel dalam penelitian ini dilakukan dengan menggunakan teknik non probability sampling design dan pengambilan datanya dilakukan secara purposive. Sampel yang selanjutnya menjadi responden secara keseluruhan adalah: 2 (dua) orang dokter penangggung jawab, 4 (empat) orang dokter jaga, 10 (sepuluh) orang perawat orang tenaga kesehatan. Alat yang digunakan dalam penelitian lapangan adalah dengan dengan menggunakan pedoman wawancara secara semi struktur.

Selanjutnya. analisis yang dipergunakan dalam penelitian ini adalah analisis kualitatif secara yuridis normatif berdasarkan konsep-konsep yang diperoleh melalui 
studi dokumen dan wawancara. Berdasarkan analisis tersebut, akan diperoleh gambaran yang menyeluruh mengenai asas-asas hukum, prinsip-prinsip hukum dan ketentuan-ketentuan hukum yang berkaiatan dengan permasalahan.

\section{PEMBAHASAN}

Seorang pasien dalam keadaan darurat, pada prinsipnya akan kehilangan kompetensinya. Hal ini disebabkan pasien pada umumnya dalam kondisi tidak sadarkan diri. Oleh karena itu, dalam kaitan ini pasien tidak mempunyai kemampuan untuk menilai, tidak memupunyai kemampuan untuk memahami dan tidak mempunyai kemampuan untuk menalar. Padahal untuk melihat seorang pasien mempunyai kompetensi atau tidak ada tiga syarat yang harus dipenuhi, yaitu: ${ }^{1}$ kemampuan untuk menilai, kemampuan untuk memahami, dan kemampuan untuk menalar.

Pada umumnya pasien yang masuk ke Instalasi Gawat Darurat (IGD) adalah pasien yang membutuhkan pertolongan dengan cepat dan tepat. Untuk itu harus ada standar dalam memberikan pelayanan gawat darurat sesuai dengan kompetensi dan kemampuan tenaga kesehatan yang melayaninya, sehingga dapat menjamin suatu penanganan gawat darurat dengan response time yang cepat dan penanganan yang tepat. Mengenai standar pelayanan di IGD secara normatif telah diatur dalam Keputusan Menteri Kesehatan Republik Indonesia No. 856/Menkes/SK/IX/2009 Tentang Standar Instalasi Gawat Darurat (IGD) Rumah Sakit.

Selanjutnya, menurut ketentuan Pasal 4 Permenkes No. 290 Tahun 2008, secara tegas ditentukan:

1. Dalam keadaan gawat darurat, untuk menyelamatkan jiwa pasien dan/atau mencegah kecacatan tidak diperlukan persetujuan tindakan kedokteran (informed consent).

2. Keputusan untuk melakukan tindakan kedokteran sebagaimana dimaksud pada ayat (1) diputuskan oleh dokter atau dokter gigi dan dicatat di dalam rekam medik.

3. Dalam hal dilakukannya tindakan kedokteran sebagaimana dimaksud pada ayat (1) dokter atau dokter gigi wajib memberi penjelasan sesegera mungkin kepada pasien setelah pasien sadar atau kepada keluarga terdekat.

\footnotetext{
${ }^{1}$ Bertens. 2001, Op Cit. Hlm 82-83
} 
Selain itu, dalam ketentuan Pasal 45 ayat (1) UU No. 29 Tahun 2004 juga secara tegas ditetapkan, bahwa "dalam keadaan gawat darurat untuk menyelamatkan jiwa pasien tidak diperlukan persetujuan tindakan medis (informed consent)". Namun setelah pasien sadar atau dalam kondisi yang sudah memungkinkan, segera diberikan penjelasan atau persetujuan.

Berdasarkan ketentuan di atas, menunjukkan bahwa informed consent tidak diperlukan dalam keadaan darurat. Sebagai contoh, apabila ada pasien korban kecelakaan lalu lintas dalam keadaan tidak sadar dibawa ke IGD yang keadaannya sudah sangat gawat dan tidak ada waktu lagi untuk mencari atau menghubungi anggota keluargannya terlebih dahulu untuk meminta persetujuan, maka dalam hal ini dokter harus segera mengambil tindakan. Alasannya adalah bahwa tindakan medis yang dilakukan dokter tersebut semata-mata untuk menolong dan menyelamatkan jiwa pasien. Dalam konteks ini menolong jiwa pasien adalah lebih tinggi kepentingannya dari pada masalah informed consent. Lagi pula secara logika menurut kewajaran seseorangtidak akan menolak jika ada yang hendak menolong jiwanya. Oleh karena itu dalam kasus seperti ini pasien dianggap menyetujui (presumed consent). Secara konkret dalam kasus demikian dokter harus mengambil tindakan menyelamatkan jiwa pasien (life-saving) atau menyelamatkan anggota tubuh pasien (limb-saving). Artinya, bahwa dokter harus segera bertindak tanpa ragu-ragu lagi tanpa meminta izin pasien terlebih dahulu, karena waktu adalah sangat berharga untuk menolong jiwa pasien.

Selanjutnya, dalam praktik di di IGD para tenaga kesehatan terutama tenaga medis sering kali menghadapi masalah dalam melakukan tindakan medis terhadap pasien gawat darurat. Hal ini pernah dikemukakan oleh dua orang dokter penangungjawab ruangan dan empat dokter jaga, bahwa dalam melakukan tindakan medik terhadap pasien gawat darurat sering mengalami masalah terutama adanya tuntutan dari pihak yang mengatasnamakan keluarga. ${ }^{2}$ Padahal tujuan utama melakukan tindakan medis adalah untuk menyelamatkan jiwa pasien. Kondisi ini umumnya pada tindakan berupa bedah cito. ${ }^{3}$ Tuntutan tersebut, bukan hanya ditukan

\footnotetext{
${ }^{2}$ Wawancara dengan responden dokter tanggal 31 Agustus 2016.

3 'Cito' berasal dari kata Latin yang bermakna segera (immediately), bedah cito atau operasi emergency adalah suatu tindakan bedah yang dilakukan dngan tujuan life saving pada seorang pasien yang berada dalam keadaan darurat. Selain bedah cito dikenal juga operasi elektif dan operasi one day care. Operasi elektif adalah suatu tindakan bedah yang dilakukan terjadwal dengan persiapan, bukan bertujuan bagai life safing, dan dilakukan pada pasien dengan kondisi baik, bukan gawat darurat.
} 
pada tenaga medis saja melainkan juga kepada tenaga keperawatan yang bertugas di IGD. Menurut penuturan enam orang perawat IGD, bahwa sering kali keluarga pasien melakukan tuntutan berupa ancama bila keluarganya yang ditangani di IGD tanpa informed consent, padahal tindakan tersebut dibenarkan menurut peraturan yang berlaku. ${ }^{4}$ Selain itu, empat tenaga keperawatan yang pernah tugas di IGD mengemukakan bahwa sering mengalami kesulitan jika dihadapkan pada pasien korban kecelakaan yang tidak diantar atau didampingi pihak keluarganya. Kesulitan tersebut pada intinya kekhawatiran adanya tuntutan dari pihak keluarga kalau tenaga kesehatan yang ada di IGD melakukan pembedahan atau tindakan lainnya yang sifatnya mempunyai risiko tinggi. ${ }^{5}$

Berdasarkan informasi dari para informan tersebut, menunjukkan bahwa penerapan informed consent dalam praktiknya di IGD cukup menimbulkan persoalan terutama kekhawatiran tenaga kesehatan terhadap adanya tuntutan keluarga pasien. Bahkan tuntutan tersebut bukan hanya dari keluara pasien saja melainkan ada pihak ketiga yang mengatasnamakan keluarga pasien. ${ }^{6}$ Pihak ketiga yang mengatasnamakan keluarga pasien tersebut, bukan hanya menanyakan tentang prosedur informed consent, tetapi juga meminta rekam medik pasien. ${ }^{7}$

Berkaitan dengan pelayanan gawat darurat, Pasal 29 huruf c UU No. 44 Tahun 2009 tentang Rumah Sakit menegaskan bahwa salah satu kewajiban rumah sakit adalah memberi pelayanan gawat darurat kepada pasien sesuai dengan kemampuan pelayanannya. Bahkan menurut Pasal 32 UU No. 36 Tahun 2009 tentang Kesehatan secara tergas ditetapkan, bahwa:

1. Dalam keadaan darurat fasilitas pelayanan kesehatan, baik pemerintah maupun swasta wajib memberikan pelayanan kesehatan bagi penyelamatan nyawa pasien dan mencegah kecacatan terlebih dahulu.

2. Dalam keadaan darurat fasilitas pelayanan kesehatan, baik pemerintah maupun swasta dilarang menolak pasien dan/atau meminta uang muka.

Selanjutnya berkaitan dengan Pasal 32 di atas, Pasal 190 No. 36 Tahun 2009 tentang Kesehatan, menetapkan, bahwa:

\footnotetext{
${ }^{4}$ Wawancara dengan responden tenaga keperawatan tanggal 1 September 2016.

${ }^{5}$ Wawancara dengan responden tenaga keperawatan tanggal 5 September 2016.

${ }^{6}$ Wawancara dengan responden dokter tanggal 31 Agustus 2016.

${ }^{7}$ Wawancara dengan responden tenaga keperawatan tanggal 5 September 2016.
} 
1. Pimpinan fasilitas pelayanan kesehatan dan/atau tenaga kesehatan yang melakukan praktik atau pekerjaan pada fasilitas pelayanan kesehatan yang dengan sengaja tidak memberikan pertolongan pertama terhadap pasien yang dalam keadaan gawat darurat sebagaimana dimaksud dalam Pasal 32 ayat (2) atau Pasal 85 ayat (2) dipidana dengan pidana penjara paling lama 2 (dua) tahun dan denda paling banyak Rp200.000.000,00 (dua ratus juta rupiah).

2. Dalam hal perbuatan sebagaimana dimaksud pada ayat (1) mengakibatkan terjadinya kecacatan atau kematian, pimpinan fasilitas pelayanan kesehatan dan/atau tenaga kesehatan tersebut dipidana dengan pidana penjara paling lama 10 (sepuluh) tahun dan denda paling banyak Rp1.000.000.000,00 (satu miliar rupiah).

Berdasarkan ketentuan Pasal 29 huruf c UU No. 44 Tahun 2009 tentang Rumah Sakit dan Pasal 32 serta Pasal 190 No. 36 Tahun 2009 tentang Kesehatan, menunjukkan bahwa penanganan pasien dalam keadaan darurat harus dengan respon cepat dan penanganan yang tepat

Berdasarkan wawancara dengan empat dokter jaga di IGD mengemukakan bahwa menurut peraturan di atas dalam praktik seringkali rumah sakit mendapatkan rujukan pasien yang pada dasarnya pasien yang dirujuk tersebut tidak sesuai dengan klasifikasi rumah sakit yang dituju. Hal ini agak menylitkan dalam pelayanan mengingat peralatan yang tidak begitu lengkap. ${ }^{8}$ Apa yang dikemukakan oleh responden dokter tersebut pada prinsipnya sesuai dengan ketentuan Pasal 29 huruf c UU No. 44 Tahun 2009 tentang Rumah Sakit menegaskan bahwa salah satu kewajiban rumah sakit adalah memberi pelayanan gawat darurat kepada pasien sesuai dengan kemampuan pelayanannya.

Berdasarkan uraian di atas, penerapan informed consent dalam praktek pelayanan kesehatan pada pasien gawat darurat di rumah sakit harus tetap sesuai dengan kondisi fasilitas dan tenaga kesehatan yang ada dan sesuai dengan klasifikasi rumah sakitnya. Selain itu, pelayanan gawat darurat harus diselenggarakan 24 (dua puluh empat) jam sehari secara terus menerus.

Pada prinsipnya penerapan informed consent di IGD tidaklah mutlak diperlukan, karena dalam konteks ini tindakan medis yang dilakukan semata-mata

\footnotetext{
${ }^{8}$ Wawancara dengan responden dokter tanggal 31 Agustus 2016.
} 
untuk menolong jiwa pasien. Menyelamatkan jiwa pasien adalah lebih tinggi kepentinggannya dari pada masalah informed consent. Selain itu, menurut kewajaran seseorang tidak akan menolak jika ada yang hendak menolong jiwa dalam keadaan darurat. Menurut penuturan beberapa orang informan baik dokter maupun perawat, bahwa hambatan utama dalam pelayanan darurat adalah ketidakfahaman pasien dan keluarganya dalam pelayanan medis di IGD. Sebagai contoh konkret adalah ada pasien yang datang terlebih dahulu tetapi tidak langsung mendapat perawatan. Kondisi ini pada umumnya dianggap oleh keluarga pasien sebagai penelantaran atau membiarkan pasien tidak ditangani dengan segera. Padahal, dalam konteks ini ada pasien lain yang mengalami penyakit yang lebih serius dan membutuhkan pertolongan segera. Oleh karena itu di sebuah IGD ada prinsip triase ${ }^{9}$ yang merupakan metode Perawatan Gawat Darurat (PPGD), yang mendahulukan pasien yang terancam jiwanya atau berisiko kecacatan. Tujuan triase perawatan gawat darurat adalah:

1. Identifikasi cepat korban yang memerlukan stabilisasi segera, Ini lebih ke perawatan yang dilakukan di lapangan.

2. Identifikasi korban yang hanya dapat diselamatkan dengan pembedahan.

3. Untuk mengurangi jatuhnya korban jiwa dan kecacatan.

Menurut informasi yang diberikan oleh informan dokter di IGD ada tiga pengelompokan triase berdasarkan tag label, yaitu: ${ }^{10}$

1. Prioritas Nol (Hitam), adalah: Pasien meninggal atau cedera Parah yang jelas tidak mungkin untuk diselamatkan.

2. Prioritas Pertama (merah), adalah: penderita cedera berat dan memerlukan penilaian cepat dan tindakan medik atau transport segera untuk menyelamatkan hidupnya. Misalnya penderita gagal nafas, henti jantung, luka bakar berat, pendarahan parah dan cedera kepala berat.

3. Prioritas kedua (kuning), adalah: pasien memerlukan bantuan, namun dengan cedera dan tingkat yang kurang berat dan dipastikan tidak akan mengalami

9 Triase berasal dari bahasa Perancis artinya "menseleksi", yaitu teknik untuk menentukan prioritas penatalaksanaan pasien atau korban saat "sumber daya terbatas". Perhatian dititik beratkan pada pasien atau korban dengan kondisi medis yang paling urgent dan paling besar kemungkinan untuk diselamatkan.

${ }^{10}$ Wawancara dengan responden dokter tanggal 31 Agustus 2016 
ancaman jiwa dalam waktu dekat. misalnya cedera abdomen $^{11}$ tanpa shok, luka bakar ringan, fraktur atau patah tulang tanpa shok dan jenis-jenis penyakit lain.

4. Prioritas Ketiga (hijau), adalah pasien dengan cedera minor dan tingkat penyakit yang tidak membutuhkan pertolongan segera serta tidak mengancam nyawa dan tidak menimbulkan kecacatan.

Tiga kriteria dalam pengelompokan triase tersebut pada umumnya tidak difahami oleh pasien maupun keluarganya, sehingga seolah-olah kalau pasien sudah masuk IGD harus ditangani dengan segera. Kondisi inilah yang paling krusial dihadapi oleh tenaga kesehatan di IGD terutama para tenaga keperawatan. ${ }^{12}$

Hambatan lain yang cukup krusial dalam pelayanan di IGD adalah masalah perluasan operasi (extended operation). ${ }^{13}$ Pada prinsipnya dokter dalam mengambil tindakan harus membatasi operasinya hanya pada apa yang termasuk tindakan penyelamatan jiwa (life-saving) atau penyelamatan anggota tubuh (limb-saving) saja. Tidak diperkenankan diperluas dengan operasi lain yang secara langsung tidak ada hubungannya dengan tindakan penyelamatan atau anggota tubuh pasien. Namun dalam praktik di IGD kemungkinan-kemungkinan untuk operasi tambahan dapat terjadi pada seorang pasien. Seperti pada pasien yang menjadi korban kecelakaan lalulintas.

Dua hal yang menjadi penghambat dalam pelayanan medis di IGD tersebut pada umumnya selalu dapat diatasi. Namun dalam konteks ini perlu penjelasan-penjelasan yang sifatnya khusus terutama kepada keluarga pasien

Aspek hukum yang berkaitan dengan penerapan informed consent pada pelayanan darurat, pada prinsipnya harus tetap mengacu pada standar profesi, standar pelayanan rumah sakit dan standar prosedur operasional. Hal ini sebagaimana ditegaskan dalam Pasal 13 ayat (3) UU no. 44 Tahun 2009, yaitu: "Setiap tenaga kesehatan yang bekerja di Rumah Sakit harus bekerja sesuai dengan standar profesi,

${ }^{11}$ Abdomen adalah istilah medis yang digunakan untuk menggambarkan bagian diantara dada (bagian paling bawah tulang rusuk) dan pelvis atau bagian paling atas dari paha. Pada manusia, abdomen identik dengan kata perut. Trauma abdomen adalah terjadinya cedera atau kerusakan pada organ abdomen yang menyebabkan perubahan fisiologi sehingga terjadi gangguan metabolisme, kelainan imunologi dan gangguan faal berbagai organ.

${ }_{12}^{12}$ Wawancara dengan responden tenaga keperawatan tanggal 5 September 2016.

13 Dalam suatu pembedahan kadang-kadang dijumpai patologi lain yang dapat dilakukan operasi saat itu juga, namun ada pula dalam keadaan normal yang dianggap oleh dokter berpotensi menimbulkan masalah dikemuasian hari (seperti apendiks/usus buntu). Pada prinsipnya secara hukum operasi tambahan tersebut harus ada izin tersendiri dari pasien atau keluarganya, kecuali bila patologi itu membahayakan jiwa pasien bila tidak segera diambil suatu tindakan. 
standar pelayanan Rumah Sakit, standar prosedur operasional yang berlaku, etika profesi, menghormati hak pasien dan mengutamakan keselamatan pasien. Secara lebih spesifik untuk untuk mengatasi hambatan dalam pelayanan di IGD tenaga kesehatan baik tenaga medis maupun tenaga keperawatan harus berpedoman pada Keputusan Menteri Kesehatan Republik Indonesia No. 856/Menkes/SK/IX/2009. Artinya, dalam hal ini rumah sakit harus memiliki Standar Instalasi Gawat Darurat sehingga dapat memberikan pelayanan dengan respon cepat dan penanganan yang tepat. Dengan kata lain, pasien yang masuk ke IGD rumah sakit harus mendapatkan pertolongan yang cepat dan tepat untuk itu perlu adanya standar dalam memberikan pelayanan gawat darurat sesuai dengan kompetensi dan kemampuannya sehingga dapat menjamin suatu penanganan gawat darurat dengan response time yang cepat dan penanganan yang tepat.

Pelayanan medis di IGD, dalam praktiknya juga mengalami kendala adanya teamwork yang tidak efektif, banyak pelayanan kesehatan yang seharusnya tidak dilakukan oleh perawat justru dilakukan guna memberi rasa nyaman kepada pasien dan keluarganya. Menurut kaedah hukum kesehatan, tugas seorang perawatan adalah to care, yaitu memberi perawatan, namun dalam praktik perawat juga melakukan to cure atau pengobatan. Hal ni dapat dibenarkan asalkan tindakan perawat melakukan pengobatan tersebut atas perintah dokter, yang dalam hal ini dokter secara yuridis harus bertanggung jawab atas perintahnya tersebut.

Persepsi lain yang ada pada keluarga pasien menurut penuturan para informan dokter, bahwa pasien datang ke IGD untuk mendapatkan kesembuhan. ${ }^{14}$ Padahal dalam prinsip pelayanan medis yang dilakukan dokter bersama tenaga kesehatan lain harus bekerja semaksimal mungkin berdasarkan standar profesi, pengalaman dan ilmu pengetahuan dan kondisi rumah sakit. Oleh karena itu, dapat saja pasien diberikan tindakan medis ternyata tidak memberi kesembuhan. Hal ini dapat saja terjadi karena kompleksitas dan perjalanan penyakit pasien kian kronis. Selain itu dapat terjadi adanya risiko medis yang melekat pada diri pasien. Kondisi demikian ini dalam postulat pelayanan medis tidak semua pasien yang mendapatkan perlakuan medis menghasilkan dampak positif.

\footnotetext{
${ }^{14}$ Wawancara dengan responden dokter tanggal 31 Agustus 2016
} 
Ada asas yang mengatakan bahwa dalam keadaan darurat tidak mengenal hukum (necessitas non habet legem) ${ }^{15}$. Oleh karena itu, dalam kajian yuridis tenaga kesehatan yang memeberi pelayanan medis di IGD pada prinsipnya juga diberlakukan asas necessitas non habet legem. Oleh karena itu dalam praktik pelayanan medis dimungkinkan adanya penyimpangan terhadap kaedah hukum tertentu yang tidak dikenai sanksi, di sini terdapat penyimpangan atau pengecualian-pengecualian (de uitzonderingen bevestigen de regel $^{16}$ ). Bahkan dalam ilmu hukum dikenal adanya pelanggaran-pelanggaran hukum yang dilakukan dalam keadaan tertentu, yang pada prinsipnya perbuatan-perbuatan itu dapat dikempokan menjadi dua yaitu:

1. Perbuatan yang pada hakikatnya merupakan pelanggaran kaedah hukum, tetapi tidak dikenakan sanksi karena dibenarkan atau mempunyai dasar pembenar (rechtvaardigingsground). Dalam konteks ini perbuatan pada hakikatnya melanggar kaedah hukum yang dihalalkan. Termasuk perbuatan ini adalah, keadaan darurat, pembelaan terpaksa, ketentuan undang-undang dan perintah jabatan.

2. Perbuatan yang pada hakikatnya merupakan pelanggaran kaedah hukum, tetapi tidak dikenakan sanksi karena si pelaku pelanggaran dibebaskan dari kesalahan (schuldopheffingsgrond). Perbuatan ini terjadi karena apa yang dinamakan force mayeur, overmacht atau keadaan memaksa, yaitu suatu keadaan atau kekautan di luar kemampuan manusia.

Beranjak dari ketentuan Pasal 4 ayat (1) Permenkes No. 290 Tahun 2008, maka dapat dibenarkan bahwa: "Dalam keadaan darurat, untuk menyelamatkan jiwa pasien dan/atau mencegah kecacatan tidak diperlukan persetujuan tindakan kedokteran". Namun demikian, selanjutnya ditegaskan dalam ayat (2) bahwa keputusan untuk melakukan tindakan kedokteran sebagaimana dimaksudkan pada ayat (1) diputuskan oleh dokter atau dokter gigi dan dicatat dalam rekam medik. Dalam hal dilakuknnya tindakan kedokteran sebagaimana dimaksudkan pada ayat (1)

\footnotetext{
${ }^{15}$ Menurut Aristoteles, kedaruratan adalah penggerak pertama (prime mover), kedaruratan tidak perlu dicari dasar hukumnya, karena dari awal kedaruratan itu sudah berwatak hukum.

${ }^{16}$ Menurut Sudikno Mertokusumo dalam Bukunya Teori Hukum, 2011, Penerbit Universitas Atma Jaya Yogyakarta,. Hlm. 46-47, bahwa dengan adanya penyimpangan-penyimpangan atau pengecualian-pengecualian itulah yang memperkuat berlakunya asas hukum yang bersifat umum. Misalnya setiap orang diwajibkan untuk menolong sesama, ini adalah asas hukum yang bersifat universal. Apalagi kalau seorang tenaga medis ada seorang pasien yang memerlukan pelayanan medis, maka secara hukum ia wajib menolong sesuai dengan kemampuannya.
} 
dokter atau dokter gigi wajib memberikan penjelasan sesegera mungkin kepada pasien sadar atau kepada keluarga pasien.

Berdasarkan ketentuan di atas, dapat ditarik kesimpulan bahwa tindakan medis dalam keadaan darurat tetap harus dicatatkan dalam rekam medis ${ }^{17}$. Pencatatan isi rekam medis untuk pasien gawat darurat, menurut Pasal 3 ayat (3) Permenkes No. 269/Menkes/Per/III/2008 sekurang-kurangnya memuat: Identitas pasien, kondisi saat pasien tiba di sarana pelayanan kesehatan, identitas pengantar pasien, tanggal dan waktu, hasil anamnesis, mencakup sekurang-kurangnya keluhan dan ruwayat penyakit, hasil pemeriksaan fisik dan penunjang medik, diagnosis, pengobatan dan/atau tindakan, ringkasan kondisi pasien sebelum meninggalkan pelayanan unit gawat darurat dan rencana tindak lanjut, nama dan tanda tangan dokter, dokter gigi, atau tenaga kesehatan tertentu yang memberikan pelayanan kesehatan, sarana transportasi yang digunakan bagi pasien yang akan dipindahkan ke sarana pelayanan kesehatan lain dan pelayanan lain yang telah diberikan kepada pasien.

\section{PENUTUP}

Berdasarkan hasil penelitian dan pembahasan di atas, dapat simpulkan, sebagai berikut:

1. Penerapan informed consent dalam praktek pelayanan kesehatan pada pasien gawat darurat di rumah sakit, pada prinsipnya telah mengikuti peraturan yang berlaku, yaitu bahwa dalam keadaan darurat informed consent tidak diperlukan. Namun demikian, masih timbul kekhawatiran di kalangan tenaga kesehatan bahwa tidak adanya informed consent akan menimbulkan tuntutan dari keluarga pasien.

2. Hambatan pelayanan gawat darurat di IGD adalah bahwa pada umumnya keluarga pasien tidak memahami prosedur pelayanan medis di IGD yang mengenal sistem triase, adanya perluasan operasi (extended operation) yang mungkin timbul dan adanya teamwork yang kurang efektif.

3. Penerapan informed consent dalam pelayanan gawat darurat di IGD secara yuridis mengandung makna adanya penyimpangan-penyimpangan terhadap kaedah medis. Namun penyimpangan yang dimaksud merupakan pengecualian,

17 Rekam medis (medical record) menurut ketentuan Pasal 1 angka 1 Permenkes No. 269/Menkes/Per/III/2008, adalah berkas yang berisikan catatan dan dokumen tentang identitas pasien, pemeriksaan, pengobatan, tindakan dan pelayanan lain yang telah diberikan kepada pasien. 
bahwa penyimpangan tersebut tidak dikenakan sanksi dan dibenarkan secara hukum

\section{DAFTAR PUSTAKA}

\section{Buku}

Bertens, K. 201. Etika Biomedis. Penerbit Kanisius, Yogyakarta.

Chandrawila, Wila Supriadi. 2001. Hukum Kedokteran. Penerbit Mandar Maju, Bandung.

Greene, Brendan. 2005. Understanding Medical Law. by Gavendish Publishing Oregon, USA.

Guwandi, J. 2004. Informed Consen., Penerbit Fakultas Kedokteran Universitas Indonesia, Jakarta.

Guwandi, J. 2006. Informed Consent dan Informed Refusal. Penerbit Fakultas Kedokteran Universitas Indonesia, Jakarta.

Hanafiah, Jusuf dan Amri Amir. 2011. Etika Kedokteran dan Hukum Kesehatan, Penerbit Buku Kedokteran EGC, Jakarta.

Hendrick, Judith. 2000, Law and Ethics in Nursing and Health Care. Published by Stamley Thornes Ltd, United Kingdom.

Herkutanto. 2007. Aspek Medikolegal Pelayanan Gawat Darurat, Majalah Kedokteran Indonesia Vol.57 No.2.

Jenie, Siti Ismijati. 2007 "Itikad Baik, Perkembangan Dari Asas Hukum Khusus Menjadi Asas Hukum Umum di Indonesia", Pidato Pengukuhan Jabatan Guru Basar pada Fakultas Hukum Universitas Gadjah Mada, Yogyakarta.

Kjeruik, Diane K. dan Edith Ann Brous. 2010. Law and Ethics for Advanced Practice Nursing. Springer Publishing Caompany LLC, New York.

Komalawati, Veronica. 1989. Hukum dan Etika dalam Praktik Dokter. Penerbit Pustaka Sinar Harapan, Jakarta.

Kuma Astuti, Endang. 2009. Transaksi Terapeutik dalam Upaya Pelayanan medis di Rumah Sakit. Penerbit Citra Aditya Bhakti, Bandung.

Mertokusumo, Sudikno. 2011. Teori Hukum. Penerbit Universitas Atmajaya, Yogyakarta 
Muhammad, Kartono. 1991. Informed Consent. Rumah Sakit Pusat Pertamina dan Fakultas Hukum Universitas Indonesia, Jakarta.

Staunton, Patricia dan Mary Chiarella. 2008, Nursing and The Law, By BPA Print Group, Australia .

Switankowsky, Irene S. 1998. A New Paradigm for Informed Consent. University Press of Amerika, USA.

Wellman, Carl. 2005. Medical Law and Moral Right. Published by Springer Dordrecht, Netherlands 